\title{
Effectiveness of Cloud based E-Learning System (ECBELS)
}

\author{
Divya. $P$ \\ M.Phil(cs) Research scholar, \\ Department of Computer Science and Applications, \\ SCSVMV University, Enathur. \\ Kanchipuram
}

\author{
S. Prakasam M.C.A, Ph.D., \\ HOD \& Associate Professor, \\ Department of Computer Science and Applications, \\ SCSVMV University, Enathur, \\ Kanchipuram
}

\begin{abstract}
Education system is gradually developing due to the continuous development of technology. E-learning in universities is very important to deliver the materials to students and conduct tests. All the materials are stored in servers and delivered to students. Storing the materials in servers requires a lot of investment in hardware. Delivering the contents to the students at anytime and anywhere with less investment is the main motive of most universities. E-learning based on cloud computing provides such an environment. In this research, we proposed architecture for e-learning based on cloud computing and presents a security issues in cloud computing, which we have to check before moving e-learning into the cloud.
\end{abstract}

Keywords: E-learning, Cloud computing, ICT

\section{INTRODUCTION}

E-learning is commonly referred to the intentional use of networked information and communications technology (ICT) in teaching and learning. The growth of e-learning is directly related to the increasing access to ICT, as well as its decreasing cost. Cloud computing is becoming an attractive technology due to its dynamic scalability and effective use of the resources; it can be utilized under circumstances where the availability of resources is limited. Cloud computing deliver services autonomously based on demand and provides sufficient network access, data resource environment and effectual flexibility. This technology is used for more efficient and cost effective computing by centralizing storage, memory, computing capacity of PC's and servers. With the tremendous advantages of cloud computing, we expect this technology to revolutionize the field of e-learning education [1]. The main goal of Cloud Based E-Learning System (CBELS) is to meet the needs of the students such as clarifying the doubts from trained teachers and accessing materials required for their academic purpose.

\section{LITERATURE REVIEW}

Mohammed Al-Zoube [2] has presented a virtual and personal learning environment. It combines a wide range of technologies and tools for education. The author builds the proposed environment to support formal and informal learning, and to enable mashup of various learning services and applications. The proposed cloud based personalized elearning system have three major functionalities: Web-based course management system (CMS), Personalized Learning Environment (PLE), Smart Agents.

Faten Karim et.al [3] discussed some of the theories in the learning field. The author illustrates the building blocks of elearning \& traditional learning and the emergence of elearning. It also describes about the emergence of cloud computing in e-learning and advantages of e-learning when implementing in cloud computing.

Dinesh H A et.al [4] focused on rural schools in providing a quality education. It discusses about the problems faced by Indian Rural Education Environment. To solve this, the author proposed advanced technologies and tools like Virtualization, cloud computing technology, Moodle which help in fixing the problems faced by them.

D. Kasi Viswanath et.al [5] discusses about the cloud computing definitions, types of cloud services and cloud service providers. Web Based Training (WBT) is one of the advancement of computer technologies which works with the help of preprogrammed software applications. Cloud based elearning has five layers, namely hardware resource layer, software resource layer, resource management layer, service layer and business application layer. The expected benefits and issues regarding the cloud based e-learning architecture are also discussed.

Table 1.1 Comparative table of existing cloud based e-learning:

\begin{tabular}{|c|c|c|c|}
\hline $\begin{array}{c}\text { Author and } \\
\text { Title }\end{array}$ & Functionality & Advantage & $\begin{array}{l}\text { Disadvanta } \\
\text { ge }\end{array}$ \\
\hline $\begin{array}{l}\text { "E-Learning } \\
\text { in a cloud } \\
\text { computing } \\
\text { environment } \\
\text { ", } 2014 \\
\text { IEEE, } \\
\text { Mohammed } \\
\text { Ketel. }\end{array}$ & $\begin{array}{l}\text { It describes } \\
\text { about the } \\
\text { major needs } \\
\text { to which } \\
\text { institutions } \\
\text { need to adapt } \\
\text { and factors } \\
\text { that affect the } \\
\text { adoption of } \\
\text { cloud } \\
\text { computing in } \\
\text { academic } \\
\text { institutions }\end{array}$ & $\begin{array}{l}\text { It presents } \\
\text { advances in } \\
\text { technology } \\
\text { that will } \\
\text { help } \\
\text { pushing E- } \\
\text { Learning in } \\
\text { the cloud, } \\
\text { like an } \\
\text { increase in } \\
\text { bandwidth, } \\
\text { reduced cost } \\
\text { of storage, } \\
\text { virtualizatio } \\
\text { n. }\end{array}$ & $\begin{array}{l}\text { Implementin } \\
g \text { E- } \\
\text { Learning in } \\
\text { cloud } \\
\text { computing } \\
\text { will cause of } \\
\text { management } \\
\text { problems } \\
\text { such as how } \\
\text { to manage } \\
\text { teaching and } \\
\text { learning, the } \\
\text { content } \\
\text { courses, the } \\
\text { examination } \\
\text { and } \\
\text { students. }\end{array}$ \\
\hline $\begin{array}{l}\text { "E-Learning } \\
\text { system } \\
\text { architecture } \\
\text { based in } \\
\text { private cloud } \\
\text { for } \\
\text { university", } \\
2014 \text { Journal } \\
\text { of Chemical }\end{array}$ & $\begin{array}{l}\text { It discusses } \\
\text { about the } \\
\text { definition of } \\
\text { cloud } \\
\text { computing, } \\
\text { existing cloud } \\
\text { providers and } \\
\text { proposes a } \\
\text { new }\end{array}$ & $\begin{array}{l}\text { From the } \\
\text { proposed } \\
\text { architecture, } \\
\text { the } \\
\text { advantages } \\
\text { are } \\
\text { virtualizatio } \\
\mathrm{n}, \\
\text { collaborativ }\end{array}$ & $\begin{array}{l}\text { When } \\
\text { coming to } \\
\text { security } \\
\text { related } \\
\text { problems in } \\
\text { cloud based } \\
\text { e-learning, } \\
\text { the proposed } \\
\text { architecture }\end{array}$ \\
\hline
\end{tabular}




\begin{tabular}{|c|c|c|c|}
\hline $\begin{array}{l}\text { and } \\
\text { Pharmaceutic } \\
\text { al Research, } \\
\text { Wang } \\
\text { Shunye, Liu } \\
\text { Dayong and } \\
\text { Zhang Zijuan }\end{array}$ & $\begin{array}{l}\text { architecture } \\
\text { with } 5 \\
\text { systems: } \\
\text { educational } \\
\text { administratio } \\
\text { n, on-line } \\
\text { learning, } \\
\text { teaching } \\
\text { resources, } \\
\text { virtual lab, } \\
\text { and online } \\
\text { communicatio } \\
\text { n. }\end{array}$ & $\begin{array}{l}\text { e learning, } \\
\text { personalized } \\
\text { learning, } \\
\text { computation } \\
\text { al ability } \\
\text { and storage } \\
\text { capability, } \\
\text { cost. }\end{array}$ & lacks in it. \\
\hline $\begin{array}{l}\text { "A Review } \\
\text { of cloud } \\
\text { deployment } \\
\text { models for } \\
\text { E-Learning } \\
\text { systems", } \\
2013 \text { IEEE, } \\
\text { Engine } \\
\text { Leloglu, } \\
\text { Tolga Ayav, } \\
\text { Burak Galip } \\
\text { Aslan. }\end{array}$ & $\begin{array}{l}\text { It describes } \\
\text { about the } \\
\text { deployment } \\
\text { models, } \\
\text { benefits with } \\
\text { respect to the } \\
\text { cloud based } \\
\text { E-Learning } \\
\text { systems } \\
\text { solutions and } \\
\text { risks besides } \\
\text { these benefits. }\end{array}$ & $\begin{array}{l}\text { Based on } \\
\text { the different } \\
\text { deployment } \\
\text { models, it } \\
\text { provides } \\
\text { alternatives } \\
\text { to build } \\
\text { cloud-based } \\
\text { E-learning } \\
\text { system. }\end{array}$ & $\begin{array}{l}\text { It provides } \\
\text { to build the } \\
\text { cloud based } \\
\text { e-learning } \\
\text { system } \\
\text { based upon } \\
\text { only three } \\
\text { deployment } \\
\text { models, } \\
\text { however, } \\
\text { debates } \\
\text { about cloud } \\
\text { deployment } \\
\text { models still } \\
\text { have not } \\
\text { come to an } \\
\text { end. }\end{array}$ \\
\hline $\begin{array}{l}\text { "Enhancing } \\
\text { Cloud based } \\
\text { E-learning } \\
\text { using } \\
\text { Knowledge } \\
\text { Sharing } \\
\text { System", } \\
2013 \\
\text { International } \\
\text { Journal of } \\
\text { Computer } \\
\text { Applications, } \\
\text { Aruna.R and } \\
\text { S.Prakasam }\end{array}$ & $\begin{array}{l}\text { It proposes a } \\
\text { new } \\
\text { architecture } \\
\text { called cloud } \\
\text { based e- } \\
\text { learning using } \\
\text { the } \\
\text { knowledge } \\
\text { sharing } \\
\text { system. This } \\
\text { architecture } \\
\text { includes open } \\
\text { educational } \\
\text { resources, } \\
\text { mobile } \\
\text { education, } \\
\text { curriculum } \\
\text { development, } \\
\text { etc. It also } \\
\text { discusses } \\
\text { some security } \\
\text { issues related } \\
\text { to cloud } \\
\text { based e- } \\
\text { learning. }\end{array}$ & $\begin{array}{l}\text { The main } \\
\text { advantage } \\
\text { of the } \\
\text { proposed } \\
\text { architecture } \\
\text { is a forum. } \\
\text { It facilitates } \\
\text { the student } \\
\text { to learn } \\
\text { themselves } \\
\text { and shares } \\
\text { their views } \\
\text { \& ideas. }\end{array}$ & $\begin{array}{l}\text { It does not } \\
\text { provide any } \\
\text { guidance for } \\
\text { security } \\
\text { issues } \\
\text { related to } \\
\text { cloud based } \\
\text { e-learning. }\end{array}$ \\
\hline $\begin{array}{l}\text { "A Novel } \\
\text { Approach for } \\
\text { Adopting } \\
\text { Cloud-based } \\
\text { E-Learning } \\
\text { System", } \\
2012 \text { IEEE, } \\
\text { MD.Anwar } \\
\text { Hossain } \\
\text { Masud and }\end{array}$ & $\begin{array}{l}\text { It discusses } \\
\text { about the } \\
\text { public cloud } \\
\text { environment } \\
\text { and } \\
\text { challenges } \\
\text { faced by the } \\
\text { cloud based } \\
\text { e-learning. It } \\
\text { also proposes }\end{array}$ & $\begin{array}{l}\text { Features are } \\
\text { digital } \\
\text { library, } \\
\text { collaboratio } \\
\mathrm{n} \text {, online } \\
\text { storage, } \\
\text { Education } \\
\text { Software As } \\
\text { A Service. }\end{array}$ & $\begin{array}{l}\text { Even the } \\
\text { technologies } \\
\text { are } \\
\text { advancing at } \\
\text { a rapid pace, } \\
\text { the } \\
\text { traditional } \\
\text { educational } \\
\text { methods } \\
\text { cannot be }\end{array}$ \\
\hline
\end{tabular}

\begin{tabular}{|c|c|c|c|}
\hline $\begin{array}{l}\text { Xiaodi } \\
\text { Huang }\end{array}$ & $\begin{array}{l}\text { a new } \\
\text { framework } \\
\text { and it consists } \\
\text { of } \\
\text { management } \\
\text { subsystem \& } \\
\text { service } \\
\text { subsystem }\end{array}$ & & $\begin{array}{l}\text { replaced } \\
\text { with these } \\
\text { new } \\
\text { technologies } \\
\text {. }\end{array}$ \\
\hline $\begin{array}{l}\text { "Cloud } \\
\text { Based Model } \\
\text { For E- } \\
\text { Learning In } \\
\text { Higher } \\
\text { Education", } \\
2012 \\
\text { International } \\
\text { Journal of } \\
\text { Advanced } \\
\text { Engineering } \\
\text { Technology, } \\
\text { Prof.Swati } \\
\text { Vitkar }\end{array}$ & $\begin{array}{l}\text { It describes } \\
\text { about the use } \\
\text { of cloud } \\
\text { computing in } \\
\text { higher } \\
\text { education, } \\
\text { and how } \\
\text { students \& } \\
\text { teachers can } \\
\text { benefit } \\
\text { through cloud } \\
\text { based e- } \\
\text { learning }\end{array}$ & $\begin{array}{l}\text { The benefits } \\
\text { when e- } \\
\text { learning is } \\
\text { implemente } \\
\mathrm{d} \text { in cloud } \\
\text { computing } \\
\text { are access to } \\
\text { applications } \\
\text { from } \\
\text { anywhere } \\
\text { and } \\
\text { anytime, } \\
\text { students are } \\
\text { exposed to } \\
\text { new } \\
\text { technologies } \\
\text { etc. }\end{array}$ & $\begin{array}{l}\text { The } \\
\text { limitations } \\
\text { when e- } \\
\text { learning is } \\
\text { implemente } \\
d \text { in cloud } \\
\text { computing } \\
\text { are security } \\
\text { and lack of } \\
\text { speed of } \\
\text { internet can } \\
\text { affect the } \\
\text { performance } \\
\text { if cloud } \\
\text { based e- } \\
\text { learning }\end{array}$ \\
\hline
\end{tabular}

\section{ARCHITECTURE OF CLOUD BASED E-LEARNING SYSTEM}

The proposed architecture consists of five layers: Learning Layer, Administration Layer, Resource Layer, Forum Layer and Virtual Lab. The figure 1.1 shows the proposed architecture of Cloud Based E-Learning System (CBELS).

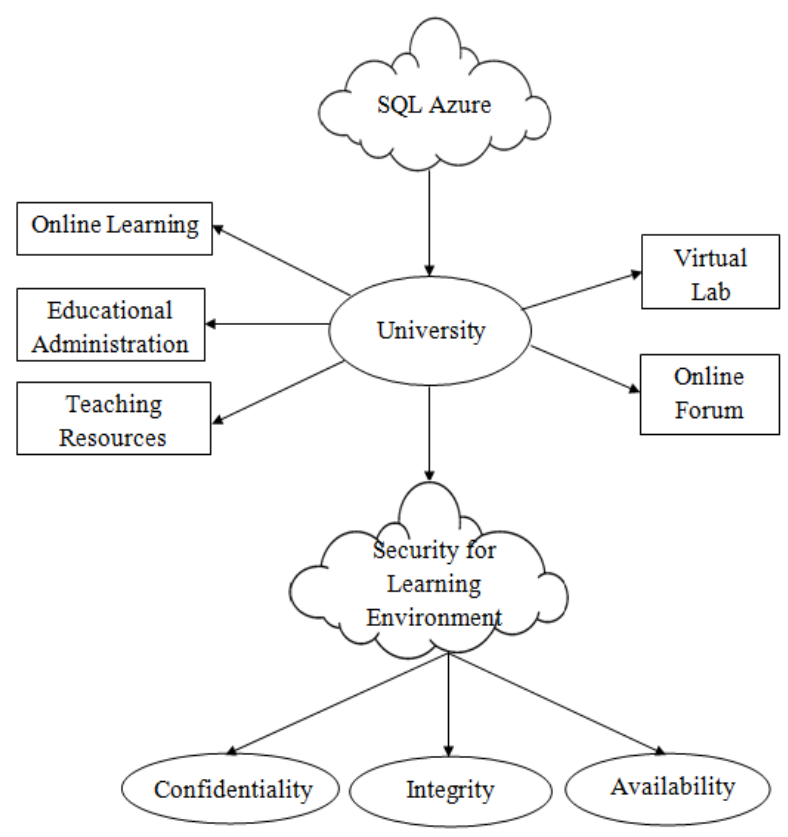

Figure 1.1: Architecture of Cloud Based E-Learning System (CBELS)

Learning Layer: This layer is most important in E-Learning architecture. The students learn the materials, answers the question at the end and can able to get the marks of them. 


\begin{abstract}
Administration Layer: Administration layer manages the students' information, teachers' information and course management.
\end{abstract}

Resource Layer: This layer consists of materials regarding to education, such as reference documents, videos and audios.

Forum Layer: In this layer students can ask questions regarding their subjects and get answers immediately. Both teachers and students can answer questions posted in this layer.

Virtual Lab: Software's needed by students for their education are uploaded by the staff's in this layer.

\subsection{Security in Cloud Based E-learning:}

Cloud security is a set of policies and technologies to protect data and applications from unauthorized entities. Security is a primary concern when we are moving the e-learning system in the cloud.

Information security depends on the three principles of confidentiality (who has access), integrity (correctness of information), and availability (ability to access information and services at appropriate times). These elements constitute computer security in any context, and they take on new significance in cloud computing because it depends on thirdparty providers. Higher education is subject to regulations concerning the protection of student records and other data, and individual campuses tend to be idiosyncratic with respect to state or local requirements and cultural attitudes towards risk. In this context, any institution that turns to cloud computing faces important questions about how information assets will be safeguarded and what measures are in place to secure those assets over time [12].

\section{Confidentiality:}

Confidentiality ensures that the sensitive data is accessed by only authorized entities. From the point of e-learning environment, the students and teachers need the assurance that they are accessing the e-learning materials in private and the administration need assurance that any other institution is not accessing their materials [13].

\section{Integrity:}

Integrity ensures that unauthorized entities are not modifying, creating, appending or deleting the e-learning contents [13].

\section{Availability:}

Availability ensures the students and teachers can access the e-learning contents at any time and any place. The e-learning contents should be made available to the teachers and students $24 / 7$ [13].

Cloud security involves the same fundamental issues as any computer security program: restricting access to authorized users, maintaining the integrity of data, and ensuring the availability of data and services. When data and services reside on servers, external to the campus, however, safeguarding those assets involves additional concerns. Encrypting data in transit is important, as are the service provider's security procedures. Cloud computing typically uses server virtualization, and if the virtualization isn't secure, data from one segment of a server could "escape" into another area. Frequency and reliability of data backups are important, as is the recoverability of data in the event of a glitch or data loss [12].

\subsection{Threats in Confidentiality, Integrity and Availability:}

The table 1.2 provides an overview of the threats for Cloud Based E-Learning System categorized according to the confidentiality, integrity and availability (CIA) [14] \& [15].

Table 1.2 Threats in Confidentiality, Integrity and Availability

\begin{tabular}{|c|c|}
\hline EAT & IION \\
\hline $\begin{aligned} & \begin{array}{l}\text { Confidentiality } \\
\text { 1. }\end{array} \begin{array}{l}\text { Insider user threats } \\
\text { (malicious cloud } \\
\text { provider or customer } \\
\text { user). }\end{array} \\
& \text { 2. } \begin{array}{l}\text { External attacker } \\
\text { threats } \quad \text { (remote } \\
\text { software attack of } \\
\text { cloud application) }\end{array} \\
& \text { Data leakage (Failure } \\
& \text { of electronic and } \\
& \text { physical transport } \\
& \text { systems for e-learning } \\
& \text { data and backups) }\end{aligned}$ & $\begin{array}{l}\text { Confidentiality is an } \\
\text { important aspect in } \\
\text { security concerns, where } \\
\text { the e-learning materials in } \\
\text { the cloud is to be kept as } \\
\text { secret. }\end{array}$ \\
\hline 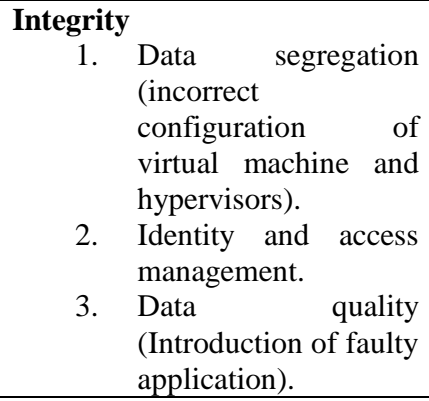 & $\begin{array}{l}\text { Information or data is not } \\
\text { accidentally or maliciously } \\
\text { deleted or changed, and it } \\
\text { should be kept accurate as } \\
\text { in the original form. } \\
\text { Students and teachers need } \\
\text { the assurance that the e- } \\
\text { learning materials are not } \\
\text { modified or deleting it by } \\
\text { unauthorized persons. }\end{array}$ \\
\hline 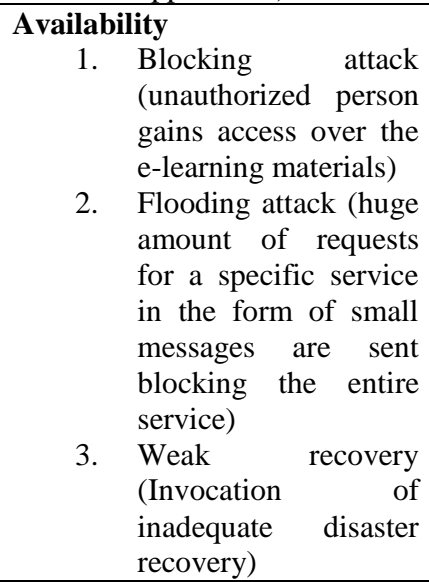 & $\begin{array}{l}\text { The reliable information } \\
\text { should be present to access } \\
\text { and modify it by } \\
\text { authorized persons. } \\
\text { Information present in e- } \\
\text { learning servers must be } \\
\text { present for students and } \\
\text { teachers or other } \\
\text { authorized persons on } \\
\text { timely manner for their } \\
\text { work. }\end{array}$ \\
\hline
\end{tabular}

\subsection{General Requirements for Security in Cloud Based E-learning System:}

Confidentiality:

Confidentiality can be achieved through proper encryption techniques taking the type of encryption into consideration: symmetric or asymmetric encryption algorithms, also key length and key management in case of the symmetric cipher. Actually, it is all based on the cloud provider. It also depends on the customers' awareness that they can encrypt their information prior to uploading it.

Data confidentiality in the cloud is correlated to user authentication. Protecting a user's account from theft is an instance of a larger problem of controlling access to objects, 
including memory, devices, software, etc. Authentication is the process of establishing confidence in user identities, while they are presented to an information system. Lack of strong authentication can lead to unauthorized access to users account on a cloud, leading to a breach in privacy [16].

\section{Integrity:}

Cloud users should not only worry about the confidentiality of data stored in the cloud but also the data integrity. Data could be encrypted to provide confidentiality, there is, however, no guarantee that the data has not been altered while it resides in the cloud. A cloud computing provider is trusted to maintain data integrity and accuracy.

Data Integrity requirement lies in applying the due diligence within the cloud domain when accessing data. Therefore, ACID (atomicity, consistency, isolation and durability) properties of the cloud's stored data should undoubtedly be robustly imposed across all cloud computing delivery models. The cloud model presents a number of threats, including sophisticated insider attacks on these data properties.

In cloud computing, solution integrity refers to the ability of the cloud provider to ensure the reliable and correct operation of the cloud system in support of meeting its legal obligations, e.g., Service Level Agreements (SLAs), and any technical standards to which it has to conform. This encompasses protecting data while it is on the cloud premises, both cryptographically and physically; preventing intrusion and attack and responding swiftly to attacks such that damage is limited; preventing faults and failures of the system and recovering from them quickly to prevent extended periods of service outage; and protection of cloud tenants from the activities of other cloud tenants, both direct and indirect [16].

\section{Availability:}

It is very difficult to detect threats targeting the availability. Threats targeting availability can be either Network based attacks such as Distributed Denial of Service (DDoS) attacks or cloud provider availability.

Availability of SaaS application ensures that enterprises are provided with service around the clock. This involves making architectural changes in the application and infrastructural levels to add scalability and high availability. A multi-tier architecture needs to be adopted, supported by a loadbalanced farm of application instances, running on a variable number of servers. Resiliency to hardware/software failures, as well as to denial of service attacks, needs to be built from the ground up within the application [16].

\subsection{Implementing the Architecture of Cloud Based E-Learning System:}

The constructed work of Cloud Based E-Learning System enables the administration to easy management of course materials. Cloud Based E-Learning System allows the administration to save cost and allows the students to interact with teachers and with their friends to clear doubts. It is also possible to maintain the documents and software's which are needed by the students for their academic use.

The Cloud Based E-Learning System has the following functional units:

- Student management

- Staff management

- Course management

- File management

○ Document management
- Multimedia management

- Software management

- Online test management

- Feedback
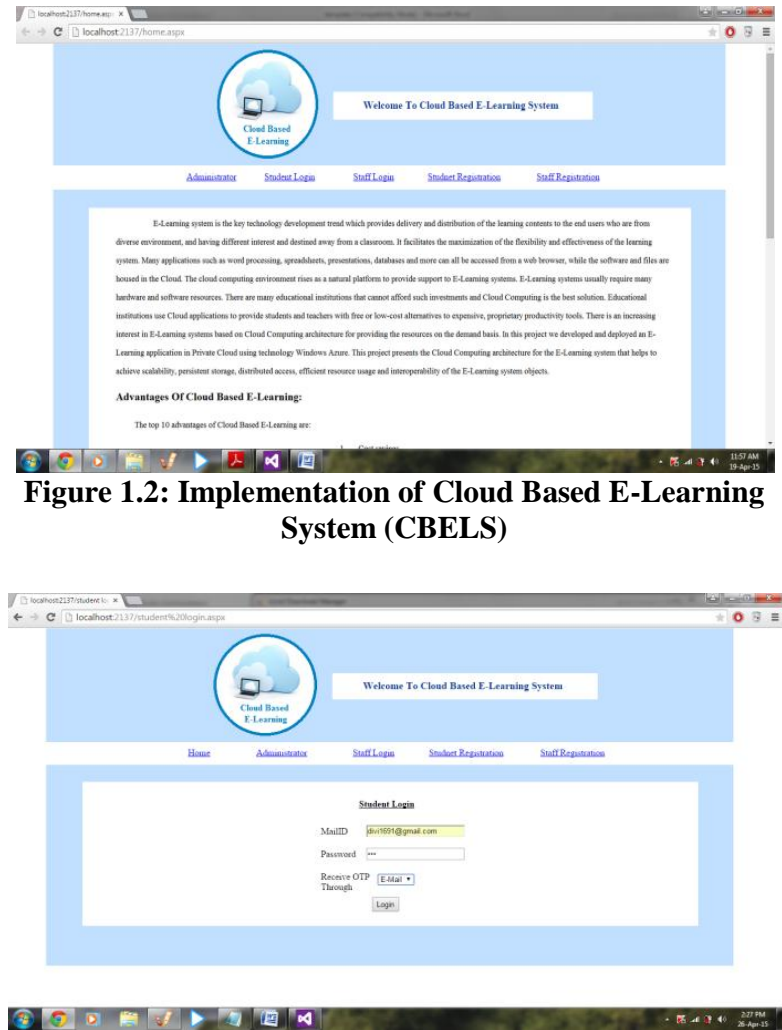

Figure 1.3: Login

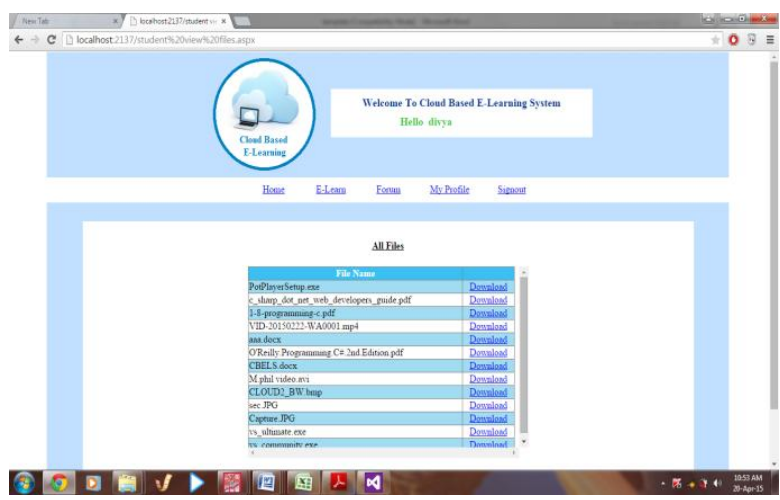

Figure 1.4: File Upload and Download

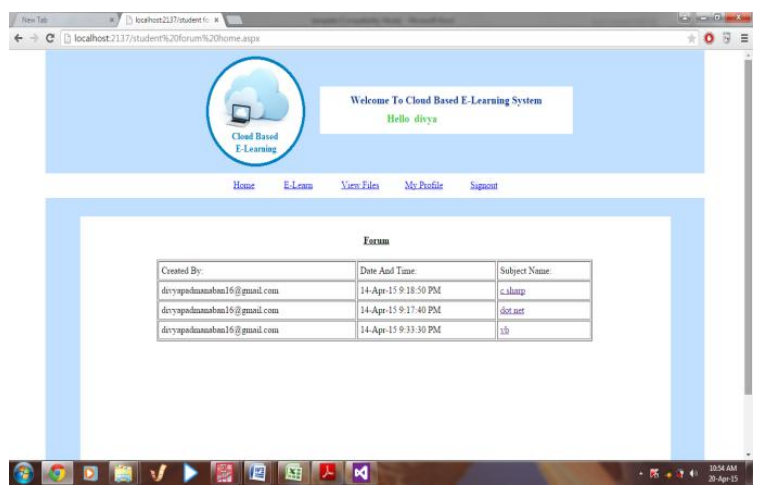

Figure 1.5: Forum 


\section{PERFORMANCE EVALUATION OF CLOUD BASED E-LEARNING SYSTEM}

A study has been conducted to measure the effectiveness of Cloud Based E-Learning System among the students of SCSVMV University.

\subsection{Population and Sample:}

To find the effectiveness of Cloud Based E-Learning System (CBELS), a study has been conducted with the students of SCSVMV University. Number of respondents based on gender are shown in the table 1.3:

Table 1.3 No. of Respondents based on Gender

\begin{tabular}{|l|r|r|}
\hline \multicolumn{1}{|c|}{ Gender } & No. of respondents & \multicolumn{1}{c|}{ Percentage } \\
\hline Female & 143 & 46.6 \\
\hline Male & 164 & 53.4 \\
\hline Total & $\mathbf{3 0 7}$ & $\mathbf{1 0 0}$ \\
\hline
\end{tabular}

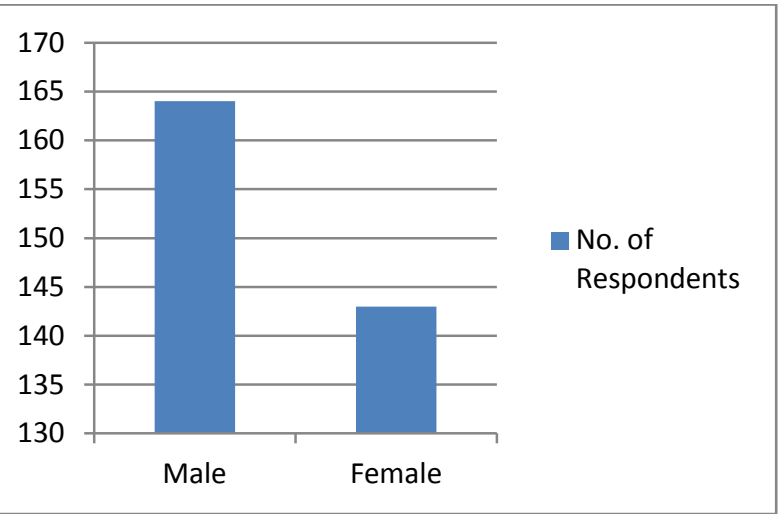

Figure 1.6: No. of Respondents Based on Gender

Table 1.4 Have attended online courses before, No. of hours spent on computer for educational purposes and No. of hours spent per week on online for learning based on gender

\begin{tabular}{|c|c|c|c|c|}
\hline & \multicolumn{2}{|c|}{ Gender } & \multirow[b]{2}{*}{ Total } \\
\hline & & Female & Male & \\
\hline \multirow{2}{*}{$\begin{array}{l}\text { Have you attend } \\
\text { online course }\end{array}$} & no & 22 & 59 & 81 \\
\hline & yes & 121 & 105 & 226 \\
\hline
\end{tabular}

\begin{tabular}{|c|c|c|c|c|}
\hline \multicolumn{5}{|l|}{ before } \\
\hline \multirow{4}{*}{$\begin{array}{l}\text { No. of hours } \\
\text { spent per week } \\
\text { on online for } \\
\text { learning }\end{array}$} & $<1$ & 23 & 59 & 82 \\
\hline & 15 to20 & 22 & 35 & 57 \\
\hline & 1 to5 & 63 & 48 & 111 \\
\hline & 6to10 & 35 & 22 & 57 \\
\hline \multirow{3}{*}{$\begin{array}{l}\text { No. of hours } \\
\text { spent on } \\
\text { computer for } \\
\text { educational } \\
\text { purposes }\end{array}$} & $<1$ & 65 & 60 & 125 \\
\hline & 1 to5 & 39 & 77 & 116 \\
\hline & 6to10 & 39 & 27 & 66 \\
\hline
\end{tabular}

From the above cross tabulation, the no. of hours spent on computer for educational purposes, no. of hours spent per week on online for learning, attend online courses before based on gender were tabulated in the following manner. 22 female respondents were not attending before online courses, 121 female respondents were attended before online course. 59 male respondents were not attending before online courses, 105 male respondents were attended before online course. Female and male count was found to be 23 and 59 respondents, were spent $<1$ hour per week online for learning. Female and male count was found to be 22 and 35 respondents were spending 15 to 20 hours per week online for learning. Female and male count was found to be 63 and 48 respondents were spending 1 to 5 hours per week online for learning. Female and male count was found to be 35 and 22 respondents were spending 6 to 10 hours per week online for learning. Female and male count was found to be 65 and 60 respondents were spent $<1$ hour on computer for educational purposes. Female and male count was found to be 39 and 77 respondents were spending 1 to 5 hours on computer for educational purposes. Female and male count was found to be 39 and 27 respondents were spending 6 to 10 hours on computer for educational purposes.

\subsection{Hypothesis Tested:}

\subsubsection{Research Hypothesis $\left(H_{1}\right)$ :}

There is a significant difference between the opinions of students based on before they have attended online course.

Null Hypothesis $\left(\mathbf{H}_{0}\right)$ :

There is no significant difference between the opinions of students based on before they have attended online course.

Table 1.5 Opinions of students based on before they have attended online course

\begin{tabular}{|c|c|c|c|c|c|c|c|c|c|c|}
\hline & & \multirow[b]{2}{*}{$\mathrm{F}$} & \multirow[b]{2}{*}{ Sig. } & \multirow[b]{2}{*}{$\mathrm{t}$} & \multirow[b]{2}{*}{ df } & \multirow{2}{*}{$\begin{array}{l}\text { Sig. } \\
(2- \\
\text { tailed }) \\
\end{array}$} & \multirow{2}{*}{$\begin{array}{c}\text { Mean } \\
\text { Differen } \\
\text { ce }\end{array}$} & \multirow{2}{*}{$\begin{array}{l}\text { Std. } \\
\text { Error } \\
\text { Differe } \\
\text { nce }\end{array}$} & \multicolumn{2}{|c|}{$\begin{array}{l}95 \% \text { Confidence } \\
\text { Interval of the } \\
\text { Difference }\end{array}$} \\
\hline & & & & & & & & & Lower & Upper \\
\hline \multirow{2}{*}{$\begin{array}{l}\text { All the concepts of } \\
\text { e-learning course } \\
\text { were good and well } \\
\text { understandable }\end{array}$} & $\begin{array}{l}\text { Equal } \\
\text { variances } \\
\text { assumed }\end{array}$ & 46.957 & .000 & 4.203 & 305 & .000 & .631 & .150 & .335 & .926 \\
\hline & $\begin{array}{l}\text { Equal } \\
\text { variances } \\
\text { not assumed }\end{array}$ & & & 4.699 & 178.078 & .000 & .631 & .134 & .366 & .896 \\
\hline \multirow{2}{*}{$\begin{array}{l}\text { The concepts of c\# } \\
\text { programming in e- } \\
\text { learning course were } \\
\text { clearly explained }\end{array}$} & $\begin{array}{l}\text { Equal } \\
\text { variances } \\
\text { assumed }\end{array}$ & 8.972 & .003 & 1.467 & 305 & .144 & .206 & .140 & -.070 & .481 \\
\hline & $\begin{array}{l}\text { Equal } \\
\text { variances } \\
\text { not assumed }\end{array}$ & & & 1.616 & 172.195 & .108 & .206 & .127 & -.046 & .457 \\
\hline
\end{tabular}




\begin{tabular}{|c|c|c|c|c|c|c|c|c|c|c|}
\hline \multirow{2}{*}{$\begin{array}{l}\text { Learning materials } \\
\text { used in e-learning } \\
\text { course for the } \\
\text { concepts of c\# } \\
\text { programming were } \\
\text { good }\end{array}$} & $\begin{array}{l}\text { Equal } \\
\text { variances } \\
\text { assumed }\end{array}$ & 32.216 & .000 & -2.749 & 305 & .006 & -.403 & .147 & -.692 & -.115 \\
\hline & $\begin{array}{l}\text { Equal } \\
\text { variances } \\
\text { not assumed }\end{array}$ & & & -2.440 & 116.141 & .016 & -.403 & .165 & -.731 & -.076 \\
\hline \multirow{2}{*}{$\begin{array}{l}\text { User interface of } \\
\text { cloud based e- } \\
\text { learning system was } \\
\text { very interactive with } \\
\text { learner }\end{array}$} & $\begin{array}{l}\text { Equal } \\
\text { variances } \\
\text { assumed }\end{array}$ & 58.346 & .000 & -9.084 & 305 & .000 & -1.166 & .128 & -1.419 & -.914 \\
\hline & $\begin{array}{l}\text { Equal } \\
\text { variances } \\
\text { not assumed }\end{array}$ & & & -7.580 & 107.009 & .000 & -1.166 & .154 & -1.471 & -.861 \\
\hline \multirow[t]{2}{*}{$\begin{array}{l}\text { The quality of the } \\
\text { course content was } \\
\text { very high in level }\end{array}$} & $\begin{array}{l}\text { Equal } \\
\text { variances } \\
\text { assumed }\end{array}$ & 34.764 & .000 & -8.353 & 305 & .000 & -1.094 & .131 & -1.352 & -.837 \\
\hline & $\begin{array}{l}\text { Equal } \\
\text { variances } \\
\text { not assumed }\end{array}$ & & & -7.245 & 112.501 & .000 & -1.094 & .151 & -1.394 & -.795 \\
\hline \multirow{2}{*}{$\begin{array}{l}\text { The concept of } \\
\text { storing e-learning } \\
\text { contents in cloud } \\
\text { was good }\end{array}$} & $\begin{array}{l}\text { Equal } \\
\text { variances } \\
\text { assumed } \\
\end{array}$ & 140.461 & .000 & 4.718 & 305 & .000 & .801 & .170 & .467 & 1.135 \\
\hline & $\begin{array}{l}\text { Equal } \\
\text { variances } \\
\text { not assumed }\end{array}$ & & & 5.698 & 214.488 & .000 & .801 & .141 & .524 & 1.078 \\
\hline \multirow[t]{2}{*}{$\begin{array}{l}\text { Retrieval of e- } \\
\text { learning contents } \\
\text { from cloud was fast }\end{array}$} & $\begin{array}{l}\text { Equal } \\
\text { variances } \\
\text { assumed }\end{array}$ & 1.131 & .288 & -3.553 & 305 & .000 & -.476 & .134 & -.739 & -.212 \\
\hline & $\begin{array}{l}\text { Equal } \\
\text { variances } \\
\text { not assumed }\end{array}$ & & & -3.490 & 136.642 & .001 & -.476 & .136 & -.745 & -.206 \\
\hline \multirow{2}{*}{$\begin{array}{l}\text { The concept and } \\
\text { working of forum to } \\
\text { clear doubts was } \\
\text { good }\end{array}$} & $\begin{array}{l}\text { Equal } \\
\text { variances } \\
\text { assumed }\end{array}$ & 37.463 & .000 & -3.379 & 305 & .001 & -.403 & .119 & -.637 & -.168 \\
\hline & $\begin{array}{l}\text { Equal } \\
\text { variances } \\
\text { not assumed }\end{array}$ & & & -2.828 & 107.415 & .006 & -.403 & .142 & -.685 & -.121 \\
\hline \multirow{2}{*}{$\begin{array}{l}\text { The concept of } \\
\text { uploading and } \\
\text { downloading } \\
\text { documents, } \\
\text { software, audio and } \\
\text { video files was good }\end{array}$} & $\begin{array}{l}\text { Equal } \\
\text { variances } \\
\text { assumed }\end{array}$ & 7.293 & .007 & -1.379 & 305 & .169 & -.177 & .129 & -.430 & .076 \\
\hline & $\begin{array}{l}\text { Equal } \\
\text { variances } \\
\text { not assumed }\end{array}$ & & & -1.246 & 119.170 & .215 & -.177 & .142 & -.459 & .105 \\
\hline \multirow{2}{*}{$\begin{array}{l}\text { Security measures } \\
\text { taken in cloud based } \\
\text { e-learning system } \\
\text { were good }\end{array}$} & $\begin{array}{l}\text { Equal } \\
\text { variances } \\
\text { assumed }\end{array}$ & 50.784 & .000 & 1.874 & 305 & .062 & .223 & .119 & -.011 & .457 \\
\hline & $\begin{array}{l}\text { Equal } \\
\text { variances } \\
\text { not assumed }\end{array}$ & & & 2.338 & 232.477 & .020 & .223 & .095 & .035 & .410 \\
\hline
\end{tabular}

The independent sample T-test for the table 1.5 shows that there is a significant difference between before they have attended online course and concepts in e-learning course were understandable, Learning materials used in e-learning course was good, user interface of cloud based e-learning system was very interactive with learner, quality of the course content was very high in level, concept of storing e-learning contents in cloud was good, working of forum was good, Security measures taken in cloud based e-learning system were good, uploading and downloading files was good, concepts of c\# programming in e-learning course were clearly explained. The significant values of these constraints is less than the fixed significant value (i.e., $\mathrm{p}<0.05)$ [17]. So that null hypothesis is rejected.

\subsubsection{Research Hypothesis (H1):}

There is significant difference between opinions of students before and after using the Cloud Based E-Learning System

\section{Null Hypothesis $\left(\mathbf{H}_{0}\right)$ :}

There is no significant difference between opinions of students before and after using the Cloud Based E-Learning System 
Table 1.6 Before and After using the Cloud Based E-Learning System

\begin{tabular}{|c|c|c|c|c|c|c|c|c|}
\hline \multicolumn{9}{|c|}{ Paired Samples Test } \\
\hline \multirow{3}{*}{ pairs } & \multicolumn{5}{|c|}{ Paired Differences } & \multirow[b]{3}{*}{$\mathbf{t}$} & \multirow[b]{3}{*}{ df } & \multirow[b]{3}{*}{ Sig. (2-tailed) } \\
\hline & \multirow[b]{2}{*}{ Mean } & \multirow{2}{*}{$\begin{array}{c}\text { Std. } \\
\text { Deviation }\end{array}$} & \multirow{2}{*}{$\begin{array}{l}\text { Std. } \\
\text { Error } \\
\text { Mean }\end{array}$} & \multicolumn{2}{|c|}{$\begin{array}{l}\text { 95\% Confidence } \\
\text { Interval of the } \\
\text { Difference }\end{array}$} & & & \\
\hline & & & & Lower & Upper & & & \\
\hline $\begin{array}{l}\text { Have you used forum in any site } \\
\text { before - the concept and working of } \\
\text { forum to clear doubts was good }\end{array}$ & .420 & 1.055 & .060 & .302 & .539 & 6.976 & 306 & .000 \\
\hline $\begin{array}{l}\text { Have you uploaded and } \\
\text { downloaded documents, software, } \\
\text { audio and video files in any site } \\
\text { before - the concept of uploading } \\
\text { and downloading documents, } \\
\text { software, audio and video files was } \\
\text { good }\end{array}$ & .235 & 1.198 & .068 & .100 & .369 & 3.430 & 306 & .001 \\
\hline $\begin{array}{l}\text { Have you accessed any site with } \\
\text { security measures before }- \text { security } \\
\text { measures taken in cloud based e- } \\
\text { learning system were good }\end{array}$ & .212 & 1.074 & .061 & .091 & .332 & 3.453 & 306 & .001 \\
\hline
\end{tabular}

The parity test has been applied in order to understand the Effectiveness of Cloud Based E-Learning System (ECBELS). It is inferred that there is a significant difference exist between the opinions of students before and after using the Cloud Based E-Learning System (CBELS).

Since the null hypothesis is rejected, the obtained significant value of before and after using the forum in Cloud based ELearning System is 0.000 , the obtained significant value of before and after using the uploading and downloading files in Cloud based E-Learning System is 0.001, and the obtained significant value of before and after using the security measures in Cloud based E-Learning System is 0.001 . These values are less than the fixed significant value (i.e., $p<0.05$ ) [17]. It informs that the Effectiveness of Cloud Based ELearning System (ECBELS) was good.

\section{ADVANTAGES OF PROPOSED SYSTEM}

The potential benefits of Cloud Based E-Learning are as follows:

1. Administration need not to purchase and install any software on the PC, because the software is in online.

2. When e-learning is in the cloud we need not to worry about the software updates, because the cloud providers itself upgrades the latest version of the software. So the students, teachers and administration uses latest version every time they login.

3. Implementation can be done in a short span of time. Due to this, the needs of the learner can be given more attention as compared to IT implementation and maintenance of infrastructure.
4. Replacement of a server can be done very easily and rapidly as a clone can be created due to virtualization, thereby reducing the cloud downtime.

5. By implementing E-Learning in cloud computing, the university can reduce the investment in large hardware and software.

6. Cloud computing provides remote collaboration possibility for students. It breaks the limitation of classroom, realizes real time communication between teachers and students or students and students through virtualization technology.

\section{CONCLUSION}

The concepts of e-learning, cloud computing and threats that would influence the e-learning system when it is implemented in cloud computing have been outlined. The significant values of the parity test show that the implementation of an elearning system in the cloud was very effective. By implementing E-Learning in cloud computing, administration, teachers and students are benefiting effectively. Cloud computing would allow the students to access the learning materials from anywhere and at any time. Students need not to use memory intensive laptops. The cloud would enable students to access the materials from any device such as desktop, laptop, etc., as long as they are connected to the network. Future research will include two aspects. First, all the subjects teaching in university will be added in Cloud Based E-Learning (CBELS). Second, the proposed architecture will be implemented as mobile app and called as M-Learning. 


\section{REFERENCES}

[1] "E-Learning using Cloud Computing", 2013 International Journal of Science and Modern Engineering, by Utpal Jyoti Bora and Majidul Ahmed.

[2] "E-Learning on the Cloud", 2009 International Arab Journal of e-Technology, Mohammed Al-Zoube.

[3] "Using Cloud Computing in E-Learning Systems", 2013 International Journal of Advanced Research in Computer Science \& Technology, Faten Karim, Dr. Robert Goodwin.

[4] "Advanced Technologies and Tools for Indian Rural School Education System", 2011 International Journal of Computer Applications, Dinesha H A and Dr. V. k. Agrawal.

[5] "Cloud Computing Issues and Benefits Modern Education", 2012 Global Journal of Computer Science and Technology Cloud \& distributed, D.Kasi Viswanath, S. Kusuma \& Saroj Kumar Gupta.

[6] E-Learning in a cloud computing environment", 2014 IEEE, Mohammed Ketel.

[7] "E-Learning system architecture based in private cloud for university", 2014 Journal of Chemical and Pharmaceutical Research, Wang Shunye, Liu Dayong and Zhang Zijuan.

[8] "A Review of cloud deployment models for E-Learning systems", 2013 IEEE, Engine Leloglu, Tolga Ayav, Burak Galip Aslan.
[9] "Enhancing Cloud based E-learning using Knowledge Sharing System", 2013 International Journal of Computer Applications, Aruna.R and S.Prakasam.

[10] "A Novel Approach for Adopting Cloud-based ELearning System", 2012 IEEE, MD.Anwar Hossain Masud and Xiaodi Huang.

[11] "Cloud Based Model for E-Learning in Higher Education", 2012 International Journal of Advanced Engineering Technology, Prof.Swati Vitkar.

[12] "7 things you should know about cloud security" by Educase in august 2010.

[13] "A Novel Approach for the Security Remedial in a Cloud-based E-learning Network”, NOVEMBER 2014, JOURNAL OF NETWORKS, by Md Anwar Hossain Masud, Xiaodi Huang, and Md Rafiqul Islam.

[14] "Security and Privacy Issues in Cloud Computing", Tata Consultancy Services Ltd., Kolkata, INDIA, by Jaydip Sen,Innovation Labs.

[15] "Analysis of Security Issues in Cloud Based ELearning", university of Boras 2011, by Gunasekar kumar and Anirudh chelikani.

[16] "Security Issues In Cloud Computing", 2012 IEEE International Conference on Systems, Man, and Cybernetics, by Huaglory Tianfield.

[17] "Effectiveness of Data Mining Based E-Learning System" (DMBELS), March 2013 International Journal of Computer Applications, by M. Prema and S. Prakasam. 